\title{
Saponin production from Quillaja genus species. An insight into its applications and
}

\section{biology}

\author{
Fernando Guerra $\left.{ }^{*} \mathbb{(}\right)$, Sebastián Sepúlveda²]
}

\author{
'Universidad de Talca, Instituto de Ciencias Biológicas, Av. \\ Lircay s/n, Casilla 747, Talca, Chile. \\ ZUniversité de Lorraine, Boulevard des Aiguillettes, BP \\ 70239, 54506 Vandoeuvre-les-Nancy, France. \\ *Corresponding author <fguerra@utalca.cl>
}

Edited by: Jason James

Received November 22, 2019

Accepted March 11, 2020

\begin{abstract}
Quillaja genus (Quillajaceae family) is endemic to South America, where is represented by two species, Quillaja saponaria and Quillaja brasiliensis. One outstanding characteristic of these forest tree species is their production of saponins, a family of amphipathic glycosides, involved in the defensive response of plants against biotic and abiotic factors. Saponins are metabolites of economic importance due to their chemical and physical properties. Basic and applied research efforts performed during the last decades, mainly on Q. saponaria, have placed these compounds as an important raw material in industrial areas, such as food and beverage, cosmetics, vaccine production, biopesticides, among others. In this review, we summarize information on saponins from Quillaja species during the last years, analyzing current developments by application areas, as well as their chemical composition and properties. We also describe the general advances in revealing saponin biosynthesis pathways, related genes and Quillaja genomes, as well as the conservation status, domestication processes, and perspectives in the context of implementing genetic improvement programs.
\end{abstract}

Keywords: triterpenes, secondary metabolism, chemical structure, biosynthesis pathway, genes

\section{Introduction}

Quillaja is a genus of the Quillajaceae family of the Fabales order (Magnoliopsida) and comprises only two species: Quillaja saponaria Molina (QS) and Quillaja brasiliensis (St. A.-Hil. \& Tul.) Mart. (QB) (Mello and Cantos, 2014). Distribution of both evergreen forest tree species includes specific areas in South America. QB is endemic to southern Brazil and northeastern Argentina, eastern Paraguay and northern Uruguay, (between $21^{\circ}$ $\mathrm{S}$ and $31^{\circ} \mathrm{S}$ and from $46^{\circ} \mathrm{W}$ to $58^{\circ} \mathrm{W}$, ranging up to 1350 m.a.s.l) (Mello et al., 2014). QS is endemic to the Mediterranean regions of Chile, occurring in mixed forests, in the so-called sclerophyllous forest, and growing abundantly between $30^{\circ} \mathrm{S}$ and $38^{\circ} \mathrm{S}$, reaching up to 2000 m.a.s.l. (Schlotterberk et al., 2015). The traditional interest on this genus is because of saponins in the bark, wood, and leaves of trees (Figure 1). Both species, notably QS, represent important commercial sources of raw saponins used as a foaming, wetting, and emulsifying agent, and, in a more purified form, in preparing photographic emulsions, cosmetics, vaccine adjuvants and other medical products (Rodríguez-Díaz et al., 2011). In particular, QS is well known for its relatively high content of triterpene saponins (between $1.2 \%$ in branches and near to $16-20 \%$ of dry weight at the bark), which are specially destined to personal care products and used as vaccine adjuvants (Copaja et al., 2003; Arrau et al., 2011; Magedans et al., 2019). In Chile, annual exportation of QS extracts, bark, and wood powder registered 20.6 million U.S. dollars in 2018 (INFOR, 2019). Along with the increasing demand for QS extract, pressure on natural forests has increased in the last decades, with a prediction of an overexploitation trend for the next years (Schlotterbeck et al., 2015). Since the identification of saponins as the main metabolites in Quillaja species, many studies have investigated their composition and applications, mainly on QS and, to a lesser extent, on $\mathrm{QB}$. In the latter, characterization of saponins and the analyses of their potential uses are relatively recent (Costa et al., 2014; Cibulski et al., 2018; Wallace et al., 2017, 2019). In this review, we analyze historical aspects of the utilization of Quillaja species, and the progress in the characterization and applications of their saponins, incorporating general advances in the identification of saponin biosynthetic pathways, and related genes. In addition, we discuss considerations

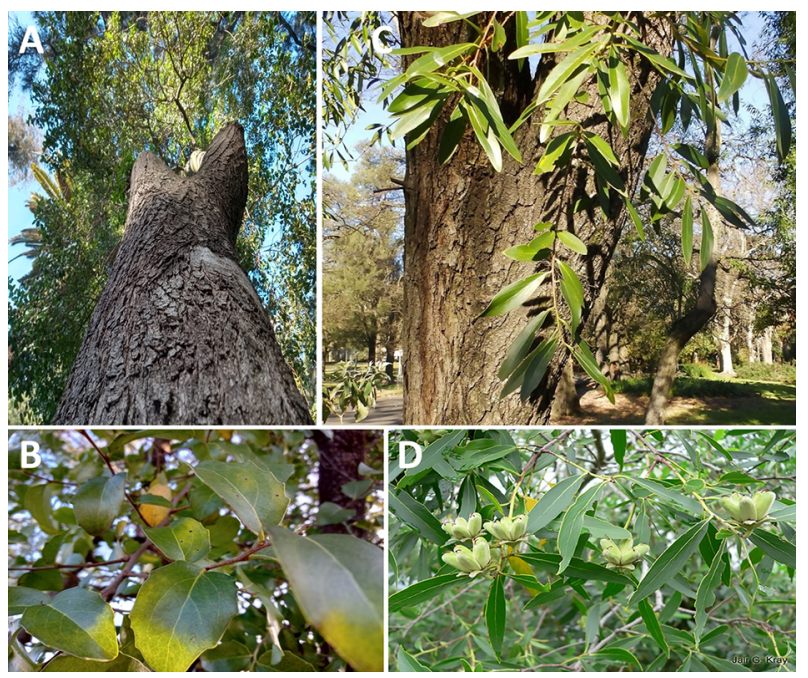

Figure 1 - Images of Quillaja saponaria (QS) and Quillaja brasiliensis (QB). A) QS bark; B) QS leaves; C) QB bark; D) QB leaves. Photography credits: A-B: Fernando Guerra and Sebastián Sepúlveda; C: Marcela Huertas Suárez; D: Jair Gilberto Kray. 
and perspectives in the framework of domestication and development of genetic improvement programs for Quillaja species.

\section{History and management of Quillaja species}

Mapuche people, the major ethnic group of southern-central Chile, have historically used the QS tree, "quillay" (a word derived from Mapuche's language "küllay" or "cúllcan", which means "to wash"), for their personal cleaning, and treating toothaches and respiratory diseases (Arrau et al., 2011; Rodríguez-Díaz et al., 2011). In 1944, its intensive exploitation encouraged the Chilean government to regulate bark extraction, promoting natural regeneration and sustainable utilization of this species. Nevertheless, illegal exploitations have continued (San Martin, 2000).

Currently, natural forests are the principal source (98\%) of raw material. The total area in Chile comprising QS (within the sclerophyllous forest) has been estimated at 230,000 ha with a biomass production of $2 \mathrm{t} \mathrm{ha}^{-1}$ every 15 years (San Martín, 2000; Schlotterbeck et al., 2015). The sustainable limit of natural forests has been estimated

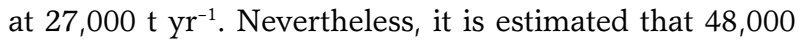
tons are required to sustain market demands by 20192020, challenging its self-renewal ability (Schlotterbeck et al., 2015). The International Union for Conservation of Nature (IUCN) qualifies this species under no risk of conservation (LC) (BGCI, 2018). The diversity of QS communities has been analyzed across 39 sites within their distribution range by Letelier et al. (2017), who estimated a Shannon-Wiener's index of 0.56, associating their presence with geographic and climate variables, and anthropogenic disturbance. Efforts for domesticating this species have been made since the middle of the last century in Chile. Important knowledge has been generated about silvicultural management focused on propagation, productive improvement of natural forests, and establishment of plantations (San Martin et al., 2000; Prehn et al., 2003; Jordan and Roveraro, 2004; Schlotterbeck et al., 2015; Vidal et al., 2016).

Production of QS derived products starts with the logging and subsequent extraction of bark pieces from 25 years-old individuals or older (Magedans et al., 2019). Then, the bark is air-dried, grounded, treated with boiled water or water-alcohol mixtures, stabilized, filtered and evaporated (San Martin, 2000). Natural regeneration produces new individuals with a bush-like architecture (multiple stems from the stump), which hinders extraction of bark from second-rotation trees. To counteract this effect, sustainable management of QS forests includes the application of thinning on new stems and the use of alternative raw material sources, such as branches from pruning and leaves (containing up to 2.58 $\% \mathrm{w} / \mathrm{w}$ of saponins) (Schlotterbeck et al., 2015). However, current industrial protocols are not designed to utilize leaves in the extraction process (Magedans et al., 2019). Starting from seeds, the germination rate depends on parental tree genetics, ranging from 61 to $92 \%$ of success
(Prehn et al., 2006). Then, seedlings are planted in the field after one growing season in a nursery, following $3 \times 3$ or $3 \times 2 \mathrm{~m}$ plantation frames (Benedetti et al., 2000). Moreover, direct organogenesis (Vidal et al., 2016) and in-vitro micropropagation (Prenh et al., 2003; Jordan and Roveraro, 2004) have been suggested as methods to optimize the vegetative multiplication of selected clones with high saponin production rates. During the 2000s, genetic improvement of QS started in Chile with mass selection of parental trees, according to their growth and industrial yield of extracts, breeding and seed orchard establishment (Velozo, 2008). A set of eight "plus" clones was generated, which was incorporated into operational plantation programs.

The increasing demand for QS saponins in the vaccine market has driven additional research to characterize equivalent saponin fractions in $\mathrm{QB}$ in the last two decades. The first publication on this subject was in 2004 (according to search performed at the Web of Science platform, in September 2019). Unlike QS, QB leaves contain more saponins than bark $(0.085 \%$ vs 0.022 $\%$ of dry weight) (Magedans et al., 2019). The renewable use of bioactive saponins from QB leaves has gained more importance in recent years (Yendo et al., 2014; Costa et al., 2013, 2014; Velazco et al., 2018; Cibulski et al., 2017-2018; Fleck et al., 2009, 2019; Wallace et al., 2017, 2019). According to the Brazilian National Center for Flora Conservation (CNCF, 2012), QB is an endangered species due to overgrazing and inadequate management, despite its economic importance. Advances in the generation of protocols for propagating QB have been produced considering seeds and tissue culture. It has been determined that $\mathrm{QB}$ seeds could maintain a germination rate of $80 \%$ after 18 months (Velazco et al., 2018). According to Fleck et al. (2009), which could be further increased when aseptic culture media are used. Additionally, the use of seeds to obtain rooted microcuttings was an efficient alternative to produce plants with saponin contents comparable to those of adult trees in field conditions (Fleck et al., 2009).

\section{Main applications of Quillaja saponins}

Traditional utilization of Quillaja saponins in the food and cosmetic industries has been associated with their foaming and emulsifying properties. However, during the last decades, two prominent areas have been developed considering their multiple inhibitory abilities and efficiency as vaccine adjuvants.

\section{Use as inhibitory agent}

Quillaja saponins and their phenolic fractions have shown a wide range of biological activities including antiallergic, antifungal, antimicrobial, anticholesterolemic, antinociceptive, anti-inflammatory, analgesic, antipyretic, antiprotozoal, molluscicide, and antiviral. Table 1 summarizes a list of studies concerning these domains, remarking the model of study used and objectives. Furthermore, QS saponins were utilized as 
biopesticide against parasitic nematodes (San Martin et al., 2005), aphids (De Geyter et al., 2012), and as a growth inhibitor of Aedes aegypti and Culex pipiens larvae (Pelah et al., 2002). One of the explanations of this inhibitory effect is the lytic activity of saponins on cell membranes (Sparg et al., 2004; de Geyter et al., 2012) as well as their capacity to change the membrane fluidity and allow macromolecules to get absorbed to or through the cells of an organism (Podolak et al., 2010; Antolak et al., 2018). In other cases, this effect was useful to prevent the attachment or viral infection through cell membranes (Roner et al., 2007; Tam and Roner, 2011) or produce membrane disorders in several organisms at high doses (Sen et al., 1998; Pelah et al., 2002). On the other hand, negative consequences have been reported during the application of saponins-based biopesticides in aquatic environments (Hassan et al., 2013; Jiang et al., 2018a, b), revealing the importance of dosage control, and on the development of beneficial yeast microflora in vineyards after treatment against Botrytis cinerea and Xiphinema index (Fischer et al., 2011).

The effects of Quillaja saponins on food digestibility have been analyzed in animal models. In vitro experiences using rumen fermentation systems have demonstrated a positive result of Quillaja saponins on the digestibility efficiency in ruminants (Pen, 2007; Bunthoeun et al., 2008; Patra et al., 2012). The same models reported the effect of QS extract in combination with Yucca schidigera saponins, reducing $\mathrm{CH}_{4}$ and $\mathrm{CO}_{2}$ emissions (Makkar et al., 1998, Bunthoeun et al., 2008). In the case of fish species, such as Nila tilapia or Cyprinus carpio, Quillaja saponins regulated female fertility, oxygen consumption (Francis et al., 2002b), and food digestibility (Serrano, 2013). Cyprinus carpio, in turn, improved growth, which was related with the lipophilic interactions of saponins with cell membranes, increasing their permeability (Francis et al., 2002b; Bunthoeun et al, 2008) and improving the nutrient intake (Francis et al., 2002a; Serrano, 2013).

\section{Use as vaccine adjuvants}

Saponins from both Quillaja species and their fractions exhibit outstanding adjuvant qualities for the development of animal and human vaccines. Table 2 summarizes a set of applications in this field. Quillaja saponins modulate the immune system of mammals used as adjuvants (Katayama and Mine, 2006; GilabertOriol et al., 2015). Nevertheless, Quillaja saponins could become unstable and induce undesirable hemolytic activity. To counteract those effects, saponins are normally used in combination with liposomes (Brunner et al., 2017) or with cholesterol and phospholipids to form a sort of self-assembled cage called the immunestimulating complex (ISCOM) (Papenmüller et al., 2014; Cibulski et al., 2018). Interestingly, the same affinity of Quillaja saponins to cholesterol is useful to fight cancer cells due to the higher membrane-cholesterol molecules content (Hu et al., 2010; Hassan et al., 2013). Marciani (2018) and Fleck et al. (2019) have described detailed information on applications of Quillaja saponins in the vaccine industry and recent pre-clinical trials extensively elsewhere, respectively.

Table 1 - List of selected studies analyzing the use of Quillaja saponins and associated extracts as inhibitory agents.

\begin{tabular}{|c|c|c|}
\hline Model & Description & Source \\
\hline \multirow[t]{2}{*}{ Bacteria } & Assessment of the potential of QS and Yucca saponins to reduce $E$. coli growth. & Sen et al. (1998) \\
\hline & $\begin{array}{l}\text { Use of QS saponins as an agent to enhance the disinfection process in the beverage industry, inhibiting } \\
\text { the growth of Asaia spp in vitro. }\end{array}$ & Antolak et al. (2018) \\
\hline \multirow[t]{2}{*}{ Fungi } & $\begin{array}{l}\text { Antifungal activity of QS saponins used as a component of cellulose nanofibrous membrane } \\
\text { against Penicillium roguefortii and Aspergillus ochraceus. }\end{array}$ & Dixit et al. (2010) \\
\hline & Activity of QS saponins and phenolic compounds against Botrytis cinerea in fresh strawberries coating. & Zúñiga et al. (2012) \\
\hline Protozoa & Evaluation of antiprotozoal activity of QS saponins against Trichomonas vaginalis. & Rocha et al. (2012) \\
\hline Virus & $\begin{array}{l}\text { Application and determination of optimal concentration of QS saponins against viruses (vaccinia virus, } \\
\text { herpes simplex virus } 1 \text {, HIV-1, HIV-2, varicella-zoster virus and retrovirus). }\end{array}$ & Roner et al. (2007) \\
\hline \multirow[t]{4}{*}{ Murine } & $\begin{array}{l}\text { Analysis of QS and Yucca saponin effects on diabetic-induced rats, reporting hypocholesterolemic, } \\
\text { hypoglycemic and antioxidant qualities of saponins. }\end{array}$ & Fidan and Dündar (2008) \\
\hline & Analgesic/antinociceptive effects of QS saponins in two murine thermal models. & Arrau et al. (2011) \\
\hline & $\begin{array}{l}\text { Assessment of antiviral activity of QS saponins against Rhesus rotavirus, by inhibition of virus-host } \\
\text { attachment. }\end{array}$ & Tam et al. (2011) \\
\hline & Testing of topical anti-inflammatory activity of quillaic acid in an inflammatory-induced mice model. & Rodríguez-Díaz et al. (2011) \\
\hline \multirow[t]{4}{*}{ Others } & Analysis of QS dry extract and their polyphenol molecules on cholesterol solubilization. & Vinarova et al., (2015) \\
\hline & Evaluation of a polyphenol-rich QS extract to retard oxidation of chicken meat lipids. & Fellenberg et al., (2011) \\
\hline & Analysis of anti-molluscicide activity of QS saponins in grey field slug. & $\begin{array}{l}\text { González-Cruz and San Martín } \\
\text { (2013) }\end{array}$ \\
\hline & Study of antimicrobial activity of QS saponins in the leather soaking process. & Zengin (2013) \\
\hline
\end{tabular}


Table 2 - List of selected studies on utilization of Quillaja saponins as vaccine adjuvants.

\begin{tabular}{|c|c|c|}
\hline Focus/application & Description & Source \\
\hline Polio vaccine & $\begin{array}{l}\text { Assessment of QB aqueous extract, QB-90 saponin fraction and Quil-A as adjuvants in a } \\
\text { polio vaccine. }\end{array}$ & Costa et al. (2014) \\
\hline Bovine viral diarrhea virus & $\begin{array}{l}\text { Study of an aqueous extract and QB- } 80 \text { saponin fraction from } \mathrm{QB} \text { as vaccine adjuvant } \\
\text { using bovine viral diarrhea virus antigen in a murine model. }\end{array}$ & Cibulski et al. (2017) \\
\hline $\begin{array}{l}\text { Porcine reproductive and } \\
\text { respiratory syndrome virus }\end{array}$ & $\begin{array}{l}\text { Evaluation of QS Quil-A saponin fraction in the up-regulation of immune genes against } \\
\text { porcine reproductive and respiratory syndrome virus. }\end{array}$ & $\begin{array}{l}\text { Charerntantanakul and Fabros } \\
\text { (2018) }\end{array}$ \\
\hline \multirow[t]{2}{*}{ Immuno-response activation } & $\begin{array}{l}\text { Study of the activation of triterpenoid saponins in the activation of dendritic cells to } \\
\text { induce immune responses. }\end{array}$ & Marciani (2018) \\
\hline & $\begin{array}{l}\text { Analysis of the suppression of allergen-specific reactivity by QS saponin in a murine } \\
\text { model of food allergy. }\end{array}$ & Katayama et al. (2006) \\
\hline \multirow[t]{2}{*}{ Anti-cancer } & $\begin{array}{l}\text { Evaluation of the potential of anticancer cholesterol-QS saponin nanoparticles against } \\
\text { lymphoma cell lines. }\end{array}$ & Hu et al. (2010) \\
\hline & $\begin{array}{l}\text { Assessment of Blocking and Balancing particles (BBE) based in the QS saponin fraction } \\
\text { Quil-A, against tumor cells of renal cell carcinoma. }\end{array}$ & Hassan et al. (2013) \\
\hline Synthetic derived adjuvants & $\begin{array}{l}\text { Analysis of Quillaja saponins limitations as vaccine adjuvant and evaluation of synthetic } \\
\text { saponins. }\end{array}$ & Adams et al. (2010) \\
\hline \multirow[t]{2}{*}{ ISCOMs } & $\begin{array}{l}\text { Study of the Quil-A saponin fraction effects on liposomal phosphatidylcholine/cholesterol } \\
\text { to form ISCOM matrices. }\end{array}$ & $\begin{array}{l}\text { Paepenmüller and Müller-Goymann } \\
\text { (2014) }\end{array}$ \\
\hline & Description of the mechanism of action of an ISCOM matrix using QB-90 saponin fraction. & Cibulski et al. (2018) \\
\hline Liposomes & $\begin{array}{l}\text { Proposition of a new method to obtain QS-21 saponin fraction and its inclusion in } \\
\text { cholesterol-based liposomes. }\end{array}$ & Brunner et al., 2017 \\
\hline
\end{tabular}

Different saponin fractions have been characterized since 1970s, with emphasis on QS, and more recently on QB. Quillaja saponaria saponin fractions, such as QS21 or their commercial presentations (e.g. Quil-A adjuvant), are widely used for the development of animal vaccines. Their use in human vaccines is under evaluation (Cibulski et al., 2018; Gilabert-Oriol et al., 2015). QS21, the most purified fraction of the aqueous extract of QS, shows some problems, such as its low concentration, difficulty in extraction and purification and/or chemical instability (Adams et al., 2010; Brunner et al., 2017). These drawbacks have promoted the development of synthetic adjuvants for the QS-21 saponin fraction. Research on chemical synthesis is still in progress; however, remarkable progress about the structure and activity of the synthetic saponins has been achieved (Fernández-Tejada et al., 2016). In parallel, QB saponins have emerged as a powerful alternative to QS saponin fractions. Indeed, QB-90, a QB fraction, has shown similar activity in comparison to Quil-A, when it is used in ISCOMs, promoting a local and transient "immunocompetent environment" (Cibulski et al., 2018). These findings are especially important for conservation and management of Quillaja species since alternative fractions from both species could be used for the development of new vaccines (Fleck et al., 2009; Costa et al., 2014; Cibulski et al., 2018).

\section{Other applications}

Quillaja saponaria saponins have particular hydrophobic and hydrophilic qualities (Kezwon and Wojciechowski, 2014; Faria et al, 2017; Reichert et al.,
2017, 2018; Xu et al., 2019). In that sense, applications have extended to mining processes and development of biosensors. San Martin et al. (2005) reported the potential of high purity Quillaja saponins to reduce oxygen bubbles burst and subsequent acid mist in copper electrowinning process, endorsing their surfactant qualities. Ramya and Sangaranarayanan (2012) described the positive surfactant effect of saponins in the synthesis of polypyrrole microfibers on platinum electrodes, used for sensing catechol, a hazardous phenolic compound that affects the central nervous system of humans.

\section{Structure of Quillaja saponins}

Quillaja saponins are special due to their triterpene nature. They have two sugar moieties attached to a central triterpene aglycone structure and are classified as bidesmosidic molecules (Van setten and van de Werken, 1996). Detailed descriptions of molecular structures of QS and/or QB saponins have already been presented (Van Setten and van de Werken, 1996; Kite et al., 2004; Fleck et al., 2019; Wallace et al., 2017, 2019). The most common triterpene aglycon skeleton is quillaic acid (Figure 2), which is generally glycosylated at C-3 and C-28 (Bankefors et al., 2010; Fleck et al., 2019). The disaccharide residue attached to C-3, $\beta$-D-Gal $\rho-(1 \rightarrow 2)-\beta$-D-GlcA $\rho$, is frequently branched at O-3 of the glucuronic acid unit by $\alpha$-L-Rha $\rho$ or a $\beta$-D-Xyl $\rho$ unit. On the other hand, C-28 is linked to a complex oligosaccharide, generally composed by a disaccharide residue $\alpha$-L-Rhap- $(1 \rightarrow 2)$ $\beta$-D-Fuc $\rho$ and different ornamentations. Some of these groups, such as 3,5-dyhydroxy-6 methyloctanoic acid, 
contribute to the adjuvant activity of Quillaja saponins (Kite et al., 2004; Fleck et al., 2019). Saponins from leaves or wood differ from those present in bark, in terms of the different terminal attached molecules (see R-groups in Table 3). According to recent studies, 58 saponins in QS bark have been reported (Fleck et al., 2019). For QB, it has been recently described 48 saponin in leaves and 54 saponins in bark (Wallace et al., 2017, 2019). Additionally, aqueous extracts of QS contain a set of other components including calcium, oxalate, proteins, sugars, and tannins (Maier et al., 2015). These components are important in determining physical characteristics, such as capacity to form foam (San Martin and Briones, 2000).

\section{Advances in the characterization of genes involved in saponin biosynthesis and Quillaja genomes}

Triterpene saponins are molecules with a defensive role in plants against biotic and/or abiotic stress factors.

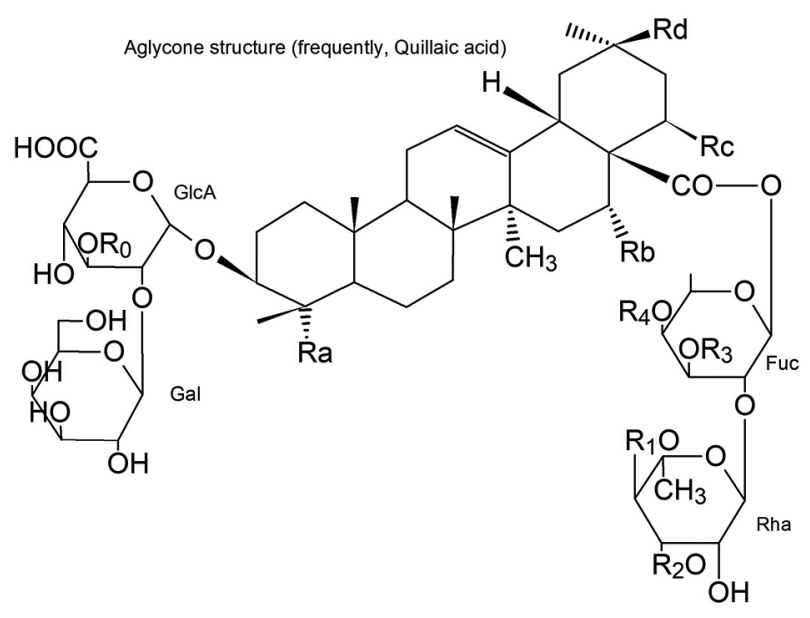

Figure 2 - General saponin bidesmosidic molecule in QS and QB (adapted from van Setten et al., 1996 and Wallace et al., 2019).
These metabolites promote plant immunity against a wide range of insects, pathogens, and herbivores (Hussain et al., 2019). The level of saponins increases in response to environmental stress (e.g water deficit) and could be involved in adaptive mechanism to survive in adverse soil and climate conditions (Szakiel et al., 2011). Saponin formation is mediated by the jasmonic and salicylic acid signaling pathways and their respective transcription factors, which upregulate the expression of key genes involved in saponin accumulation (Costa et al., 2013; Yendo et al., 2014). Yendo et al. (2014) and Kuwahara et al. (2019) present a complete description of saponin biosynthesis and illustrate the molecular transformation of different metabolites across the pathways. Briefly, saponin biosynthesis takes place in cytosol and starts from isoprenoids through the mevalonate acid pathway. Consecutively, the formed molecules are transformed by enzymes of OSC (oxidosqualene cyclases), cytochrome P450 and UDP (uridine diphosphate glycosyltransferase) families, contributing to triterpenoids molecular diversity (Luo et al., 2011; Yendo et al., 2014; Kuwahara et al., 2019). In the case of quillaic acid, the OSC $\beta$-amyrin synthase catalyzes the production of $\beta$-amyrin. Finally, enzymes of P450 and UDP families transform the $\beta$-amyrin molecule, forming quillaic acid (Meesapyodsuk et al., 2007). The knowledge of the full biosynthesis pathway for quillaic acid is still incomplete and its elucidation is a major challenge for industrial applications of saponins (Shang and Huang, 2019). According to Kamstrup et al. (2000), differences in accumulation of these compounds depends on genetic variation, which affects different enzymatic activities.

Most of the genes implicated in saponin biosynthesis are ubiquitous in plants. According to most references, genes and enzymes of Quillaja species are similar to other $\beta$-amyrin derived triterpene accumulating species. Nevertheless, characterization of new genes, for

Table 3 - Radical (R) groups in Quillaja saponin molecule (summarized from Fleck et al., 2019 and Wallace et al., 2019). Ac: acetyl group; Ara: arabinose; DeHex: dehydrohexose; Fa: 3,5 dihidroxy-octanoic acid; Glc: glucose; GlcA: glucuronic acid; Hex: hexose; MeBu: 2-methylbutanoyl; OHMeHex: 3-hydroxy-4-Methylhexanoyl; Pen: pentose; Rha: rhamnose.

\begin{tabular}{|c|c|c|c|c|c|c|c|c|c|}
\hline & RO & $\mathrm{R} 1$ & R2 & R3 & R4 & $\mathrm{Ra}$ & $\mathrm{Rb}$ & Rc & $\mathrm{Rd}$ \\
\hline \multirow{6}{*}{ QS } & Xyl & Api-Xyl & Glu & Rha & Ac & $\mathrm{CHO}$ & $\mathrm{OH}$ & $\mathrm{OH}$ & $\mathrm{CH}_{3}$ \\
\hline & Rha & Xyl-Api & $\mathrm{MeBu}$ & Fa-Ara-Rha & Fa-Ara & $\mathrm{CH}_{2} \mathrm{OH}$ & $\mathrm{H}$ & $\mathrm{H}$ & $\mathrm{COOCH}_{3}$ \\
\hline & $\mathrm{H}$ & Xyl-Xyl & $\mathrm{H}$ & Glu & OHMeHex & $\mathrm{CH}_{2} \mathrm{OCOCH}_{3}$ & & & \\
\hline & & Xyl & & GluA & $\mathrm{MeBu}$ & $\mathrm{CH}_{3}$ & & & \\
\hline & & $\mathrm{H}$ & & Ac & $\mathrm{H}$ & & & & \\
\hline & & & & $\mathrm{H}$ & & & & & \\
\hline \multirow{5}{*}{ QB } & Xyl & Xyl & Glu & Glu & $\mathrm{Fa}-\mathrm{OH}$ & & & & \\
\hline & Rha & Api & $\mathrm{H}$ & Rha & Fa-Ara & & & & \\
\hline & DeHex & Api-Xyl & & Pen & $\mathrm{Fa}$ & & & & \\
\hline & $\mathrm{H}$ & Xyl-Xyl & & Hex & & & & & \\
\hline & & $\mathrm{H}$ & & $\mathrm{H}$ & & & & & \\
\hline
\end{tabular}


example, those belonging to UDP and P450 families, has two principal challenges: 1) identify genes belonging to multigenic families in a non-sequenced organism, and 2) select an affordable number of candidate sequences for studies on functional characterization (Augustin et al., 2011). Overcome these limits is crucial to get new insights into saponin biosynthesis. Meanwhile, the increasing interest of industrial community on saponin applications and the reduction in genome sequencing costs could improve our current knowledge about the genetic basis underlying qualitative and quantitative traits determining saponin production.

QS and QB genome comprises 28 chromosomes (2n) (Kubitzki, 2007). For QS, the genome size is estimated at $821.52 \mathrm{Mbp}$ ( $0.42 \mathrm{pg}, 1 \mathrm{C}$ ) (Garcia et al., 2010). In 2015, 12 microsatellites were identified in the QS nuclear genome, which were used to analyze the pattern of genetic variation and its relationship with the spatial distribution and anthropogenic influence in Chile (Letelier et al., 2015). In 2019, a draft of the QS chloroplast genome was released (Vizoso et al., 2019). Its sequence length is $0.133 \mathrm{Mbp}$, harboring 112 putative genes, including those encoding Photosystems, RuBisCO, Cytochrome b/f complex, ribosomal subunits, among others. To the authors' knowledge, there are no other reports about the QS or QB nuclear genome or plastome sequences. According to Vizoso et al. (2019), the photosynthetic rate and methyl jasmonate-associated defensive mechanisms could be indirectly associated to saponin accumulation. They related the saponin contents with abiotic factors, under which chloroplasts may act as environmental sensors, mediating the signaling required to increase the accumulation of triterpene saponins as a defensive response. Interestingly, Costa et al. (2013) reported the same accumulation pattern for QB and linked it to similar mechanisms, as Visozo et al. (2019). Recently, Matveeva and Otten (2019) suggested the ability of Agrobacterium to induce horizontal gene transfer in QS. In their study, the authors found four bacterial genes in a QS contig sequence database. Nevertheless, due to the incomplete coverage of the contigs, it is still too early for conclusions about the presence of bacterial genes in QS genome and the possibility of its natural transformation by Agrobacterium.

\section{Final Remarks}

Quillaja saponins are well documented from a biological and chemical perspective. The wide range of applications, particularly for QS saponins, has represented several contributions to the knowledge about these metabolites since 1950. Although "omic" technologies have experienced significant advances during the last decades, and important information has been accumulated for model species, there are still important gaps for Quillaja species. These include the sequence of nuclear genomes, expression analyses (at transcriptional or protein level) focused on identifying genes and enzymes involved in saponin biosynthesis and accumulation, and the characterization of genetic mechanisms underlying its quantitative and qualitative variation, among others. Considering the increasing demand of saponins by the food, chemical, and pharmacological industries, additional actions are required to support sustainable biomass production from both natural forests and dedicated plantations. Important progress has been reached in the management and domestication of Quillaja species during the last 50 years, especially with QS in Chile. This advance has permitted to develop different protocols for biomass harvesting and management from natural forests, plant production (by seed and micropropagation), plantation and selection of high-saponin productive clones. Basic information about genetic variation and heritability regarding traits that determine biomass production, tree architecture, wood properties, concentration and diversity of saponins (and other metabolites), among others, and the identification and conservation of superior germplasm, will also contribute to developing advanced genetic improvement programs. At the same, optimization of silvicultural techniques (in forest and/ or agricultural sites), including soil and plant spacing management, use of systems for efficient water use, and the definition of biomass harvest cycles allow realizing the potential generated by breeding programs. These managed systems may take advantage of high biomass production and adaptability of Quillaja species and overcome current limitations of some non-tree species producing saponins, which are characterized by low biomass and use in food production. Progress in domestication and industrial uses of Quillaja species has been supported for governmental and private initiatives, and funding is still required in the short and mid-term. Policies promoting protection of Quillaja diversity, its forestry, as well as the development of new products or industrial processes are necessary for a sustainable use of this resource.

\section{Authors' Contributions}

Conceptualization: Guerra, F.P.; Sepúlveda, S. Software development: Sepúlveda, S. Writing and editing: Guerra, F.P.; Sepúlveda, S.

\section{References}

Adams, M.M.; Damani, P.; Perl, N.R.; Won, A.; Hong, F.; Livingston, P.O.; Ragupathi, G.; Gin, D.Y. 2010. Design and synthesis of potent quillaja saponin vaccine adjuvants. Journal of the American Chemical Society 132: 1939-1945.

Arrau, S.; Delporte, C.; Cartagena, C.; Rodríguez-Díaz, M.; González, P.; Silva, X.; Cassels, B.K.; Miranda, H.F. 2011. Antinociceptive activity of Quillaja saponaria Mol. saponin extract, quillaic acid and derivatives in mice. Journal of Ethnopharmacology 133: 164-167. 
Antolak, H.; Mizerska, U.; Berlowska, J.; Otlewska, A.; Kregiel, D. 2018. Quillaja saponaria saponins with potential to enhance the effectiveness of disinfection processes in the beverage industry. Applied Sciences 8: 368.

Augustin J.M.; Kuzina, V.; Andersen, S.B.; Bak, S. 2011. Molecular activities, biosynthesis and evolution of triterpenoid saponins. Phytochemistry 72: 435-457.

Botanic Gardens Conservation International [BGCI]. 2018. Quillaja saponaria. The IUCN red list of threatened species 2018. Available at: http://dx.doi.org/10.2305/IUCN.UK.2018-2.RLTS. T131407078A135697763.en [Accessed Oct 28, 2019]

Bankefors, J.; Nord, L.I.; Kenne, L. 2010. Multidimensional profiling of components in complex mixtures of natural products for metabolic analysis, proof of concept: application to quillaja saponins. Journal of Chromatography B 878: 471-476.

Benedetti, R.S.; Delard, R.C.; Roach, B.F. 2000. Quillay: a multipurpose alternative for central zone = Quillay: una alternativa multipropósito para la zona central. Instituto Forestal de Chile, Santiago, Chile. Available at: https://bibliotecadigital. infor.cl/handle/20.500.12220/6454 [Accessed Sep 20, 2019] (in Spanish).

Brunner, L.; Barnier-Quer, C.; Collin, N. 2017. QS-21 Adjuvant: laboratory-scale purification method and formulation into liposomes. p: 73-86. In: Fox, C.B., ed. Vaccine adjuvants: methods and protocols, methods in molecular biology. Springer, New York, NY, USA.

Bunthoeun, P.; Chetra, S.; Mwenya, B.; Takahashi, J. 2008. Effects on Quillaja saponaria extract alone or in combination with Yucca shidigera extract on ruminal fermentation and methanogenesis in vitro. Animal Science Journal 79: 193-199.

Centro Nacional de Conservação da Flora. 2012. Quillaja brasiliensis in the yellow list of Brazilian flora ver. 2012.2 = Quillaja brasiliensis in Lista Vermelha da flora brasileira versão 2012.2. Available at: http://cncflora.jbrj.gov.br/portal/pt-br/profile/ Quillaja\%20brasiliensis [Accessed Oct 26, 2019] (in Portuguese).

Cibulski, S.P.; Rivera-Patron, M.; Suárez, N.; Pirez, M.; Rossi, S.; Yendo, A.C.A.; Costa, F.; Gossman, G.; Fett-Neto, A.G.; Roehe, P.M.; Silveira, F. 2017. Leaf saponins of Quillaja brasiliensis enhance long-term specific immune responses and promote dose-sparing effect in BVDV experimental vaccines. Vaccine 36: 55-65.

Cibulski, S.P.; Rivera-Patron, M.; Mourglia-Ettlin, G.; Casaravilla, C.; Yendo, A.C.A.; Fett-Neto, A.G.; Chabalgoity, J. A.; Moreno, M.; Roehe, P.M.; Silveira, F. 2018. Quillaja brasiliensis saponinbased nanoparticulate adjuvants are capable of triggering early immune responses. Scientific Reports 8: 13582.

Charerntantanakul, W.; Fabros, D. 2018. Saponin Quil-A upregulates type I interferon-regulated gene and type I and II interferon expressions which are suppressed by porcine reproductive and respiratory syndrome virus. Veterinary Immunology and Immunopathology 195: 76-83.

Copaja, S.V.; Blackburn, C.; Carmona, R. 2003. Variation of saponin contents in Quillaja saponica Molina. Wood Science and Technology 37: 103-108.

Costa, F; Yendo, A.C.A.; Fleck, J.D.; Gosmann, G.; Fett-Neto, A.G. 2013. Accumulation of a bioactive triterpene saponin fraction of Quillaja brasiliensis leaves is associated with abiotic and biotic stresses. Plant Physiology and Biochemistry 66: 56-62.
Costa, F.; Yendo, A.C.A.; Cibulski, S.P.; Fleck, J.D.; Roehe, P.M.; Spilki, F.R.; Gosmann, G.; Fett-Neto, A.G. 2014. Alternative inactivated poliovirus vaccines adjuvanted with Quillaja brasiliensis or Quil-A saponins are equally effective in inducing specific immune responses. PLoS ONE 9: e105374.

Dixit, V.; Tewari, J.; Obendorf, S.K. 2010. Fungal growth inhibition of regenerated cellulose nanofibrous membranes containing Quillaja saponin. Archives of Environmental Contamination and Toxicology 59: 417-423.

Faria, J.T.; Oliveira, E.B.; Minim, V.P.R.; Minim, L.A. 2017. Performance of quillaja bark saponin and -lactoglobulin mixtures on emulsion formation and stability. Food Hydrocolloids 67: 178-188.

Fellenberg, M.A.; Espinoza, A.; Peña, I.; Alarcón, J. 2011. Antioxidant and bacteriostatic effects of the addition of extract of quillay polyphenols (Quillaja saponaria) in the marinade of broiler chicken. Revista Brasileira de Ciência Avícola 13: 71-79.

Fidan, A.F.; Dündar, Y. 2008. The effects of Yucca schidigera and Quillaja saponaria on DNA damage, protein oxidation, lipid peroxidation, and some biochemical parameters in streptozotocin-induced diabetic rats. Journal of Diabetes and its Complications 22: 348-356.

Fischer, M.J.C.; Pensec, F.; Demangeat, G.; Farine, S.; Chong, J.; Ramírez-Suero, M.; Mazet, F; Bertsch, C. 2011. Impact of Quillaja saponaria saponins on grapevine ecosystem organisms. Antonie van Leeuwenhoek 100: 197-206.

Fernández-Tejada, A.; Tan, D.S.; Gin, D.Y. 2016. Development of improved vaccine adjuvants based on the saponin natural product QS-21 through chemical synthesis. Accounts of Chemical Research 49: 1741-1756.

Fleck, J.D.; Schwambach, J.; Almeida, M.E.; Yendo, A.C.A.; Costa, F.; Gosmann, G.; Fett-Neto, A.G. 2009. Immunoadjuvant saponin production in seedlings and micropropagated plants of Quillaja brasiliensis. In Vitro Cellular \& Developmental Biology - Plant 45: 715-720.

Fleck, J.D.; Betti, A.H.; Silva, F.P.; Troian, E.A.; Olivaro, C.; Ferreira, F; Verza, S.G. 2019. Saponins from Quillaja saponaria and Quillaja brasiliensis: particular chemical characteristics and biological activities. Molecules 24: 171.

Francis, G.; Kerem, Z.; Makkar, H.P.S.; Becker, K. 2002a. The biological action of saponins in animal systems: a review. British Journal of Nutrition 88: 587-605.

Francis, G.; Levavi-Sivan, B.; Avitan, A.; Becker, K. 2002b. Effects of long term feeding of Quillaja saponins on sex ratio, muscle and serum cholesterol and LH levels in Nile tilapia (Oreochromis niloticus (L.)). Comparative Biochemistry and Physiology Part C 133: 593603.

Garcia S.; Garnatje, T.; Hidalgo, O.; Mas de Xaxars, G.; Pellicer, J.; Sánchez-Jiménez, I.; Vitales, D.; Valles, J. 2010. First genome size estimations for some eudicot families and genera. Collectanea Botanica 29: 7-16.

Geyter, E.; Smagghe, G.; Rahbé, Y.; Geelen, D. 2012. Triterpene saponins of Quillaja saponaria show strong aphicidal and deterrent activity against the pea aphid Acyrthosiphon pisum. Pest Management Science 68: 164-169.

Gilabert-Oriol, R.; Weng, A.; von Mallinckrodt, B.; Stöshel, A.; Nissi, L.; Melzig, M.F.; Fuchs, H.; Thakur, M. 2015. Electrophoretic mobility as a tool to separate immune adjuvant saponins from Quillaja saponaria Molina. International Journal of Pharmaceutics 487: 39-48. 
González-Cruz, D.; San Martín, R. 2013. Molluscicidal effects of saponin-rich plant extracts on the grey field slug. Ciencia e Investigación Agraria 40: 341-349.

Hassan, S.B.; Gullbo, J.; Hu, K.; Berenjian, S.; Morein, B.; Nygren, P. 2013. The nanoparticulate quillaja saponin BBE is selectively active towards renal cell carcinoma. Anticancer Research 33:143-152.

Hu, K.; Berenjian, S.; Larsson, R.; Gullbo, J.; Nygren, P.; Lövgren, T; Morein, B. 2010. Nanoparticulate quillaja saponin induces apoptosis in human leukemia cell lines with a high therapeutic index. International Journal of Nanomedicine 5: 51-62.

Hussain, M.; Debnath, B.; Qasim, M.; Bamisile, B.; Islam, W.; Hameed, M.; Wang, L.; Qiu, D. 2019. Role of saponins in plant defense against specialist herbivores. Molecules 24: 2067.

Instituto Forestal de Chile [INFOR]. 2019. Non-wood forestry products $=$ Productos forestales no madereros, INFOR, Santiago, Chile. Available at: https://bibliotecadigital.infor. cl/handle/20.500.12220/28218 [Accessed Oct 20, 2019] (in Spanish).

Jiang, X.; Cao, Y.; von Gersdorff, J.L.; Strobel, B.W.; Hansen, H.C.B.; Cedergreen, N. 2018a. Where does the toxicity come from in saponin extract? Chemosphere 204: 243-250.

Jiang, X.; Hansen, H.C.B.; Strobel, B.W.; Cedergreen, N. 2018 b. What is the aquatic toxicity of saponin-rich plant extracts used as biopesticides? Environmental Pollution 236: 416-424.

Jordan, M.; Roveraro, C. 2004. In vitro culture of Quillaja saponaria Mol. (soap-bark Tree), Rosaceae. European Journal of Horticultural Science 69 2: 73-78.

Kamstrup, S.; San Martin, R.; Doberti, A.; Grande, H.; Dalsgaard, K. 2000. Preparation and characterization of Quillaja saponin with less heterogeneity than Quil-A. Vaccine 18: 2244-2249.

Katayama, S.; Mine, Y. 2006. Quillaja saponin can modulate ovalbumin-induced $\operatorname{IgE}$ allergic responses through regulation of Th1/Th2 balance in a murine model. Journal of Agricultural and Food Chemistry 54: 3271-3276.

Kezwon, A.; Wojciechowski, K. 2014. Interaction of Quillaja bark saponins with food-relevant proteins. Advances in Colloid and Interface Science 209: 185-195.

Kite, G.C.; Howes, M.J.R.; Simmonds, M.S.J. 2004. Metabolomic analysis of saponins in crude extracts of Quillaja saponaria by liquid chromatography/mass spectrometry for product authentication. Rapid Communications in Mass Spectrometry 18: 2859-2870.

Kubitzki, K. 2007. The Families and Genera of Vascular Plants. Springer, Berlin, Germany. v. 9.

Kuwahara, Y.; Nakajima, D.; Shinpo, S.; Nakamura, M.; Kawano, N.; Kawahara, N.; Yamazaki, M.; Saito, K.; Suzuki, H.; Hirakawa, H. 2019. Identification of potential genes involved in triterpenoid saponins biosynthesis in Gleditsia sinensis by transcriptome and metabolome analyses. Journal of Natural Medicines 73: 369-380.

Letelier, L.; Harvey, N.; Valderrama, A.; Stoll, A.; GonzálezRodríguez, A. 2015. Isolation and characterization of 12 microsatellite loci in soapbark, Quillaja saponaria (Quillajaceae). Applications in Plant Sciences 3: 1500024.
Letelier, L.; Valderrama, A.; Stoll, A.; García-Gonzáles, R.; González-Rodríguez, A. 2017. Patterns of composition, richness and phylogenetic diversity of woody plant communities of Quillaja saponaria Molina (Quillajaceae) in the Chilean sclerophyllous forest. Gayana Botánica 74: 57-72.

Luo, H.; C. Sun, C.; Sun, Y.; Wu, Q.; Li, Y.; Song, J.; Niu, Y.; Cheng, X.; Xu, H.; Li, C.; Liu, J.; Steinmetz, A.; Chen, S. 2011. Analysis of the transcriptome of Panax notoginseng root uncovers putative triterpene saponin-biosynthetic genes and genetic markers. BMC Genomics 12: S5.

Magedans, Y.V.; Yendo, A.C.; Costa, F.; Gosmann, G.; Fett-Neto, A.G. 2019. Foamy matters: an update on Quillaja saponins and their use as immunoadjuvants. Future Medicinal Chemistry 11: 1485-1499.

Maier, C.; Conrad, J.; Carle, R.; Weiss, J.; Schweiggert, R.M. 2015. Phenolic constituents in commercial aqueous Quillaja (Quillaja saponaria Molina) wood extracts. Journal of Agricultural and Food Chemistry 63: 1756-1762.

Makkar H.P.S.; Sen, S.; Blümmel, M.; Becker, K. 1998. Effects of fractions containing saponins from Yucca shidigera, Quillaja saponaria, and Acacia auricoluformis on rumen fermentation. Journal of Agriculture and Food Chemistry 46: 4324-4328.

Marciani, D.J. 2018. Elucidating the mechanisms of action of saponin-derived adjuvants. Trends in Pharmacological Sciences 39: $573-585$.

Matveeva, T.V.; Otten, L. 2019. Widespread occurrence of natural genetic transformation of plants by Agrobacterium. Plant Molecular Biology 101: 415-437.

Meesapyodsuk D.; Balsevich, J.; Reed, D.W.; Covello, P.S. 2007. Saponin biosynthesis in Saponaria vaccaria. cDNAs encoding $\beta$-Amyrin synthase and a triterpene carboxylic acid glucosyltransferase. Plant Physiology 143: 959-969.

Mello, L.M.; Cantos, A.A. 2017. Space distribution model of Quillaja brasiliensis (a. St-hil. \& tul.) Mart. in south Brazil and the history of the dispersion of quillaja (quillajaceae) genus in South America. Boletín del Museo Nacional de Historia Natural 66: 297-308 (in Spanish, with abstract in English).

Paepenmüller, T.; Müller-Goymann, C.C. 2014. Influence of Quil A on liposomal membranes. International Journal of Pharmaceutics 475: 138-146.

Patra, A.K.; Stiverson, J.; Yu, Z. 2012. Effects of Quillaja and Yucca saponins on communities and select populations of rumen bacteria and archaea, and fermentation in vitro. Journal of Applied Microbiology 113: 1329-1340.

Pelah, D.; Abramovich, Z.; Markus, A.; Wiesman, Z. 2002. The use of commercial saponin from Quillaja saponaria bark as a natural larvicidal agent against Aedes aegypti and Culex pipiens. Journal of Ethnopharmacology 81: 407-409.

Pen, B.; Takaura, K.; Yamaguchi, S.; Asa, R.; Takahashi, J. 2007. Effects of Yucca schidigera and Quillaja saponaria with or without $\beta$ 1-4 galacto-oligosaccharides on ruminal fermentation, methane production and nitrogen utilization in sheep. Animal Feed Science and Technology 138: 75-88.

Podolak, I.; Galanty, A.; Sobolewska, D. 2010. Saponins as cytotoxic agents: a review. Photochemistry Reviews 9:425-474.

Prehn, D.; Serrano, C.; Berrios, C.G.; Arce-Johnson, P. 2003. Micropropagation of Quillaja saponaria Mol. starting from seeds. Bosque 2: 3-12 (in Spanish, with abstract in English). 
Ramya, R.; Sangaranarayanan, M.V. 2012. Polypyrrole microfibres synthesized with Quillaja saponin for sensing of catechol. Sensors and Actuators B: Chemical 173: 40-51.

Reichert, C.L.; Salminen, H.; Utz, J.; Badolato B.G.; Schäfer, C.; Weiss, J. 2017. Aging behavior of Quillaja saponin: pea protein interfaces. Colloid and Interface Science Communications 21: 15-18.

Reichert, C. L.; Salminen, H.; Utz, J.; Badolato B.G.; Schäfer, C.; Weiss, J. 2018. Concentration effect of Quillaja saponin: co-surfactant mixtures on emulsifying properties. Journal of Colloid and Interface Science 519: 71-80.

Rocha, T.D.; Brum V.P.; Gnoatto, S.C.B.; Tasca, T.; Gosmann, G. 2012. Anti-Trichomonas vaginalis activity of saponins from Quillaja, Passiflora, and Ilex species. Parasitology Research 110: 2551-2556.

Rodríguez-Díaz, M.; Delporte, C.; Cartagena, C.; Cassels, B. K.; González, P.; Silva, X.; León, F.; Wessjohann, L.A. 2011. Topical anti-inflammatory activity of quillaic acid from Quillaja saponaria Mol. and some derivatives. Journal of Pharmacy and Pharmacology 63: 718-724.

Roner, M.R.; Sprayberry, J.; Spinks, M.; Dhanji, S. 2007. Antiviral activity obtained from aqueous extracts of the Chilean soapbark tree (Quillaja saponaria Molina). Journal of General Virology 88: 275-285.

San Martin, R. 2000. Sustainable production of Quillaja saponaria Mol. saponins. p. 271-279. In: Oleszek, W.; Marston, A., eds. Saponins in food, feedstuffs and medicinal plants. Springer, Dordrecht, The Netherlands.

San Martın, R.; Briones, R. 2000. Quality control of commercial quillaja (Quillaja saponaria Molina) extracts by reverse phase HPLC. Journal of the Science of Food and Agriculture 80: 2063-2068.

San Martin, R.; Otero, A.F.; Figueroa, M.; Escobar, V.; Cruz, A. 2005. Use of quillaja saponins (Quillaja saponaria Molina) to control acid mist in copper electrowinning processes. Hydrometallurgy 77: 163-170.

Schlotterbeck, T.; Castillo-Ruiz, M.; Cañon-Jones, H.; San Martín, R. 2015. The use of leaves from young trees of Quillaja saponaria (Molina) plantations as a new source of saponins. Economic Botany 69: 262-272.

Sen, S.; Makkar, H.P.S.; Muetzel, S.; Becker, K. 1998. Effect of Quillaja saponaria saponins and Yucca schidigera plant extract on growth of Escherichia coli. Letters in Applied Microbiology 27: $35-38$.

Serrano, A.E. 2013. Effects of Quillaja saponins on growth, feed efficiency, digestive enzyme activities and metabolism of common carp (Cyprinus carpio L). Aquaculture Nutrition 19: 468-474.

Shang, Y.; Huang, S. 2019. Multi-omics data-driven investigations of metabolic diversity of plant triterpenoids. The Plant Journal 97: 101-111.

Sparg, S.G.; Light, M.E.; van Staden, J. 2004. Biological activities and distribution of plant saponins. Journal of Ethnopharmacology 94: 219-243.
Szakiel, A.; Paczkowski, C.; Henry, M. 2011. Influence of environmental abiotic factors on the content of saponins in plants. Phytochemistry Reviews 10: 471-491

Tam, K.I.; Roner, M.R. 2011. Characterization of in vivo antirotavirus activities of saponin extracts from Quillaja saponaria Molina. Antiviral Research 90: 231-241.

van Setten, D.C.; van de Werken, G. 1996. Molecular structures of saponins from Quillaja saponaria Molina. p. 185-193 In: Waller, G.R.; Yamasaki, K., eds. Saponins used in traditional and modern medicine. Springer, Boston, MA, USA.

Velazco, S.J.E.; Blum, C.T.; Hoffmann, P.M. 2018. Germination and seedlings development of the threatened species Quillaja brasiliensis. CERNE 24: 90-97.

Velozo, J. 2008. Final report project D03I1012: genotypic selection and industrial development of quillay extracts = Available at: http://repositorio.conicyt.cl/handle/10533/113052\# [Accessed Oct 24, 2019] (in Spanish).

Vidal C.U.J.; Ríos, D.; Sabja, A.M.; Cartes, P.; Sanchez, M. 2016. Direct organogenesis for in vitro propagation of Quillaja saponaria Molina in Southern South America. Revista Mexicana de Ciencias Forestales 7 34: 57-67.

Vinarova, L.; Vinarov, Z.; Damyanova, B.; Tcholakova, S.; Denkov, N.; Stoyanov, S. 2015. Mechanisms of cholesterol and saturated fatty acid lowering by Quillaja saponaria extract, studied by in vitro digestion model. Food \& Function 6: 1319-1330.

Vizoso, P.; Undurraga, S. F.; Velozo, J. 2019. Chloroplast genome of the soap bark tree Quillaja saponaria. Frontiers in Ecology and Evolution 7: 104.

Wallace, F.; Bennadji, Z.; Ferreira, F.; Olivaro, C. 2017. Analysis of an immunoadjuvant saponin fraction from Quillaja brasiliensis leaves by electrospray ionization ion trap multiple-stage mass spectrometry. Phytochemistry Letters 20: 228-233.

Wallace, F.; Bennadji, Z.; Ferreira, F.; Olivaro, C. 2019. Structural characterisation of new immunoadjuvant saponins from leaves and the first study of saponins from the bark of Quillaja brasiliensis by liquid chromatography electrospray ionisation ion trap mass spectrometry. Phytochemical Analysis 30: 644652.

Xu, X.; Sun, Q.; McClements, D.J. 2019. Enhancing the formation and stability of emulsions using mixed natural emulsifiers: Hydrolyzed rice glutelin and quillaja saponin. Food Hydrocolloids 89: 396-405.

Yendo, A.M.; Costa, F.; Costa, C.; Colling, L.; Gosmann, G.; FettNeto, A. 2014. Biosynthesis of plant triterpenoid saponins: genes, enzymes and their regulation. Mini-Reviews in Organic Chemistry 11: 292-306.

Zengin, A.C. 2013. Potential application of Quillaja saponaria saponins as an antimicrobial soaking agent in leather industry. Tekstil ve konfeksiyon 23: 55-61.

Zúñiga, G.E.; Junqueira-Gonçalves, M.P.; Pizarro, M.; Contreras, R.; Tapia, A.; Silva, S. 2012. Effect of ionizing energy on extracts of Quillaja saponaria to be used as an antimicrobial agent on irradiated edible coating for fresh strawberries. Radiation Physics and Chemistry 81: 64-69. 